\title{
Predictors of individual action to reduce exposure to environmental tobacco smoke
}

Ross C Brownson, James R Davis, Joan C Wilkerson, Jeannette Jackson-Thompson

\begin{abstract}
Objective-To determine the extent to which persons exposed to environmental tobacco smoke (ETS) take action to reduce exposure.
\end{abstract}

Design-Cross-sectional telephone survey.

Setting - Missouri, USA, 1991-92.

Participants - Population-based sample of Missouri residents aged $\geqslant 18$ years $(n=$ 3024).

Main outcome measures-A special series of questions was added to ascertain beliefs about ETS and actions taken to reduce individual exposure to ETS. The three primary variables of interest were (a) asking someone not to smoke in one's presence, $(b)$ asking to be seated in a nonsmoking section of a restaurant, and (c) asking about reduction of workplace smoking.

Results-Overall among nonsmokers, $34.1 \%$ of respondents had asked someone not to smoke in their presence, $77.8 \%$ had asked to be seated in a nonsmoking section of a restaurant, and $26.9 \%$ had discussed reduction of workplace smoking. The strongest sociodemographic predictors of action to reduce ETS exposure included younger age, increasing education, and metropolitan or city residence. Actions to reduce ETS exposure also were higher among: those aware of the health consequences of ETS exposure, persons who were annoyed by ETS exposure, and respondents who favoured restrictions on smoking in public places. Conclusions-Certain population subgroups are more likely to advocate protection from the health hazards of ETS exposure. Use of such data in policyoriented tobacco control projects may increase the likelihood of their success.

(Tobacco Control 1994; 3 : 216-221)

Disease Prevention and Health

Promotion, Missouri Department of Health, Columbia, Missouri, USA

RC Brownson

JR Davis

JC Wilkerson

J Jackson-Thompson

Correspondence to: Dr Ross Brownson, Department of Community Health, School of Public Health, St Louis University, 3663 Lindell

Boulevard, St Louis, MO

63108-3342, USA
Despite the well-known health effects of ETS exposure and the proliferation of state and local policies to control smoking in public places, ${ }^{7,8}$ recent evidence suggests that exposure to ETS is widespread. ${ }^{9,10}$ To combat ETS exposure in the workplace and in other public areas, the US Centers for Disease Control and Prevention (CDC) recently launched a public information campaign to increase knowledge of the dangers of ETS exposure and to empower individuals to decrease ETS exposure. ${ }^{11}$

Few published studies have examined the extent of individual action to reduce ETS exposure. To evaluate the patterns and predictors of actions to reduce exposure to ETS, we analysed recent survey data.

\section{Methods}

The Behavioral Risk Factor Surveillance System (BRFSS) was developed in 1981 by the CDC. The BRFSS provides a flexible, state health agency-based surveillance system to assist in planning, implementing, and evaluating health promotion and disease prevention programmes. ${ }^{12,13}$

We will briefly review survey methods, which have been discussed in detail elsewhere. ${ }^{12-14}$ Using random-digit dialing, ${ }^{15}$ a random sample was selected from Missouri's noninstitutionalised adult population (aged $\geqslant 18$ years) who had telephones. The survey was administered by trained interviewers during a two-week period of each month between January 1991 and December 1992. Each month, 126 interviews were conducted, for a total of 3024 interviews over the study period. Among eligible respondents (ie, working phones, non-business phone extensions), the response rate was $72 \%$. Our sample was generally representative of the overall Missouri population, ${ }^{16}$ although it underrepresented younger persons, males, and blacks (table 1).

The BRFSS instrument consists mainly of standardised questions developed by CDC. In 1991, the Missouri Department of Health added a series of questions (based mainly on earlier surveys ${ }^{17-19}$ ) to ascertain beliefs about ETS and actions taken to reduce individual exposure to ETS (table 2). A former smoker had smoked at least 100 cigarettes in his/her lifetime but did not currently smoke. A current smoker had smoked 100 cigarettes and answered "yes" to the question "Do you smoke now?" In tables 3-5, "nonsmokers" include never-smokers and former smokers, 
Table 1 Respondent characteristics by sociodemographic grouping, geographic area, and smoking status, Missouri, 1991-92

\begin{tabular}{|c|c|c|c|}
\hline Characteristic & Number & Sample $(\%)$ & Census $(\%)^{\star}$ \\
\hline \multicolumn{4}{|l|}{ Age (years) } \\
\hline $18-34$ & 955 & 31.6 & 35.9 \\
\hline $35-54$ & 1008 & 33.3 & 33.1 \\
\hline$\geqslant 55$ & 1047 & 34.6 & 30.9 \\
\hline Unknown/refused & 14 & 0.5 & \\
\hline \multicolumn{4}{|l|}{ Gender } \\
\hline Female & 1790 & 59.2 & 52.9 \\
\hline Male & 1234 & 40.8 & 47.1 \\
\hline \multicolumn{4}{|l|}{ Race } \\
\hline White & 2729 & 90.2 & 88.8 \\
\hline Black & 250 & 8.3 & 9.7 \\
\hline Other & 45 & 1.5 & 1.5 \\
\hline \multicolumn{4}{|l|}{ Education level } \\
\hline Less than high school graduate & 555 & 18.3 & 25.5 \\
\hline $\begin{array}{l}\text { High school or technical } \\
\text { school graduate }\end{array}$ & 1854 & 61.3 & 58.1 \\
\hline College graduate & 613 & 20.3 & 16.4 \\
\hline Unknown/refused & 2 & 0.1 & \\
\hline \multicolumn{4}{|l|}{ Geographic areat } \\
\hline Rural & 1055 & 34.9 & \\
\hline Metropolitan & 753 & 24.9 & \\
\hline Core cities & 1207 & 39.9 & \\
\hline Unknown/refused & 9 & 0.3 & \\
\hline \multicolumn{4}{|l|}{ Smoking status } \\
\hline Never smoker & 1541 & 51.0 & \\
\hline Former smoker & 735 & 24.3 & \\
\hline Current smoker & 745 & 24.6 & \\
\hline Unknown/refused & 3 & 0.1 & \\
\hline
\end{tabular}

* Based on the 1990 US Census population ages 18 years and older. ${ }^{16}$

† Core cities include St Louis City and County and Jackson County (includes Kansas City); metropolitan areas are other metropolitan statistical areas (as defined by the 1990 US Census ${ }^{16}$ ); rural areas are all other Missouri counties.

Table 2 Questions used to measure actions to reduce ETS exposure and beliefs about ETS, Missouri, 1991-92

\begin{tabular}{ll}
\hline Category & \multicolumn{1}{c}{ Question } \\
\hline Actions to reduce ETS exposure & In the past year, have you asked anyone not to smoke in \\
your presence? & In the past year, have you asked to be seated in the \\
nonsmoking area of a restaurant? & In the past year, have you talked with anyone where you \\
work about reducing the amount of tobacco smoke in your \\
workplace? \\
Think now for a moment about a nonsmoker who lives or \\
works with smokers. Do you think that exposure to tobacco \\
smoke is harmful or not harmful to the nonsmoker's \\
health? \\
- Is the smoke from someone else's cigarette: \\
Very annoying Somewhat annoying Not annoying \\
to you? \\
Do you think smokers should be able to smoke anywhere in \\
public places, only in certain areas, or not at all?
\end{tabular}

and "smokers" include only current smokers.

Following completion of each month's interviewing cycle, data were edited and weighted to adjust for the probability of selection, and for the age-, race-, and gender-distribution of the population. ${ }^{16,20,21} \mathrm{We}$ calculated odds ratios (OR) and $95 \%$ confidence intervals (CI), ${ }^{22}$ and utilised the exact method when called for due to a small sample size. ${ }^{23}$

\section{Results}

Approximately one-third $(34.1 \%)$ of nonsmoking respondents and $7.7 \%$ of smoking respondents had asked someone not to smoke in their presence in the previous year. Among nonsmokers, those more likely to ask someone not to smoke were persons aged 54 years and younger, blacks, persons with a high school education and greater, and city dwellers (table 3). In addition, action was higher among nonsmoking respondents who: believed that ETS was harmful, found ETS annoying, and favoured smoking restrictions in public places. Among smokers, persons aged 18 to 34 years, and those who found ETS harmful and annoying were the only variables that predicted action.

The majority $(77.8 \%)$ of nonsmokers and $32.1 \%$ of smokers had asked to be seated in a nonsmoking section of a restaurant in the previous year. Among nonsmokers, persons more likely to ask for nonsmoking seating in a restaurant included younger respondents, persons with a high school education or more, metropolitan and city residents, respondents who acknowledged the harmfulness or annoyance of ETS, and persons who favoured restrictions on public smoking (table 4).

Among eligible respondents (ie, excluding persons who worked in a smoke-free workplace, were unemployed, or retired), $26.9 \%$ of nonsmokers and $9.4 \%$ of smokers had discussed reduction of exposure to workplace ETS in the past year. In general, fewer subgroups were predictive of action to reduce workplace exposure than for variables examined in tables 3 and 4. Among nonsmokers, those significantly more likely to discuss workplace ETS reduction were persons 
Table 3 Likelihood of asking someone not to smoke in one's presence by sociodemographic grouping, geographic area, and beliefs about ETS, Missouri, 1991-92

\begin{tabular}{|c|c|c|c|c|c|c|}
\hline \multirow[b]{3}{*}{ Characteristic } & \multicolumn{6}{|c|}{ Asked someone not to smoke in one's presence } \\
\hline & \multicolumn{3}{|c|}{ Nonsmokers } & \multicolumn{3}{|c|}{ Smokers } \\
\hline & $\% \star$ & ORt & $95 \% \mathrm{CI}$ & $\% \star$ & ORt & $95 \% \mathrm{CI}$ \\
\hline \multicolumn{7}{|l|}{ Age (years) } \\
\hline$\geqslant 55$ & 20.2 & 1.0 & & 4.5 & 1.0 & \\
\hline $\begin{array}{l}35-54 \\
18-34\end{array}$ & 35.7 & 2.2 & $1.7-2.8$ & 8.1 & 1.9 & $0.8-5.3$ \\
\hline \multirow{2}{*}{\multicolumn{7}{|c|}{ Gender }} \\
\hline Male & 31.0 & 1.0 & & 7.8 & 1.0 & \\
\hline Female & 34.1 & 1.1 & $1.0-1.4$ & 8.7 & 1.1 & $0.6-1.9$ \\
\hline \multicolumn{7}{|l|}{$\begin{array}{l}\text { Race } \\
\text { White }\end{array}$} \\
\hline $\begin{array}{l}\text { White } \\
\text { Black }\end{array}$ & 32.0 & 1.0 & & 8.5 & 1.0 & \\
\hline \multicolumn{2}{|l|}{ Educational level } & 1.6 & $1.1-2.1$ & 5.7 & 0.7 & $0.2-2.3$ \\
\hline $\begin{array}{l}\text { Less than high } \\
\text { school graduate }\end{array}$ & 22.7 & 1.0 & & 5.3 & 1.0 & \\
\hline $\begin{array}{l}\text { High school or technical } \\
\text { school graduate }\end{array}$ & 34.5 & 1.9 & $1.4-2.4$ & 9.0 & 1.6 & $0.7-3.6$ \\
\hline \multirow{2}{*}{\multicolumn{5}{|c|}{$\begin{array}{l}\text { Geographic area } \neq \\
\text { Rural }\end{array}$}} & 1.6 & $0.5-4.6$ \\
\hline & 27.1 & 1.0 & & & & \\
\hline Metropolitan & 34.5 & 1.4 & $1.1-1.8$ & 10.3 & 1.4 & $0.7-2.8$ \\
\hline Core cities & 37.0 & 1.6 & $1.3-2.0$ & 7.5 & 1.0 & $0.5-2.0$ \\
\hline \multicolumn{7}{|l|}{ Presence of local ordinance $\$$} \\
\hline $\begin{array}{l}\text { No } \\
\text { Yes }\end{array}$ & 32.9 & 1.0 & & 8.3 & 1.0 & \\
\hline $\begin{array}{l}\text { Yes } \\
\text { ETS is harmful to }\end{array}$ & 32.5 & 1.1 & $0.9-1.4$ & 6.7 & 0.8 & $0.4-1.7$ \\
\hline \multicolumn{7}{|l|}{$\begin{array}{l}\text { ETS is harmful to } \\
\text { nonsmokers' health }\end{array}$} \\
\hline No & 9.2 & 1.0 & & 3.9 & 1.0 & \\
\hline Yes & 37.5 & 6.1 & $3.4-11.1$ & 11.1 & 3.1 & $1.3-9.1$ \\
\hline Don't know & 4.0 & 0.5 & $0.2-1.2$ & 3.3 & 0.8 & $0.2-3.6$ \\
\hline \multicolumn{7}{|l|}{ ETS is annoying } \\
\hline $\begin{array}{l}\text { No } \\
\text { Yes }\end{array}$ & $\begin{array}{r}7.7 \\
40.0\end{array}$ & $\begin{array}{l}1.0 \\
7.5\end{array}$ & & $\begin{array}{c}5.2 \\
15.7\end{array}$ & 1.0 & \\
\hline \multicolumn{7}{|l|}{ Smoking should be allowed } \\
\hline Anywhere & 13.8 & 1.0 & & 5.6 & 1.0 & \\
\hline Certain areas & 30.7 & 2.9 & $1.5-5.6$ & 7.9 & 1.5 & $0.6-4.8$ \\
\hline Not at all & 45.9 & 5.6 & $2.9-11.0$ & 17.7 & 3.6 & $0.8-16.0$ \\
\hline
\end{tabular}

* Weighted values; ,1 $^{1}$ unless indicated, subjects were excluded who answered "don't know" or refused to answer.

$\dagger$ Odds ratios (OR) and $95 \%$ confidence intervals (CI).

₹ Core cities include St Louis City and County and Jackson County (includes Kansas City); metropolitan areas are other metropolitan statistical areas (as defined by the 1990 US Census ${ }^{16}$ ); rural areas are all other Missouri counties.

Counties for which $\geqslant 50 \%$ of the population was covered by a comprehensive smoking control ordinance (ie, restricting smoking in workplaces, restaurants, and other public places) prior to the beginning of the study.

I Includes respondents who found ETS "very annoying" or "somewhat annoying".

Table 4 Likelihood of asking to be seated in a nonsmoking area of a restaurant by sociodemographic grouping, geographic area, and beliefs about ETS, Missouri, 1991-92

\begin{tabular}{|c|c|c|c|c|c|c|}
\hline \multirow[b]{3}{*}{ Characteristic } & \multicolumn{6}{|c|}{ Asked to be seated in a nonsmoking section } \\
\hline & \multicolumn{3}{|c|}{ Nonsmokers } & \multicolumn{3}{|c|}{ Smokers } \\
\hline & $\%$ * & ORt & $95 \% \mathrm{CI}$ & $\% \star$ & ORt & $95 \% \mathrm{CI}$ \\
\hline \multicolumn{7}{|l|}{ Age (years) } \\
\hline$\geqslant 55$ & 68.1 & 1.0 & & 25.5 & 1.0 & \\
\hline $35-54$ & 81.7 & 2.1 & $1.6-2.6$ & 32.7 & 1.4 & $0.9-2.2$ \\
\hline $18-34$ & 84.9 & 2.8 & $2.1-3.6$ & 39.9 & 2.0 & $1.2-3.1$ \\
\hline \multicolumn{7}{|l|}{ Gender } \\
\hline Male & 75.8 & 1.0 & & 33.6 & 1.0 & \\
\hline Female & 78.3 & 1.1 & $0.9-1.4$ & 34.0 & 1.0 & $0.7-1.4$ \\
\hline \multicolumn{7}{|l|}{ Race } \\
\hline White & 77.7 & 1.0 & & 33.7 & 1.0 & \\
\hline \multicolumn{7}{|l|}{ Educational level } \\
\hline $\begin{array}{l}\text { Less than high } \\
\text { school graduate }\end{array}$ & 58.2 & 1.0 & & 25.7 & 1.0 & \\
\hline $\begin{array}{l}\text { High school or technical } \\
\text { school graduate }\end{array}$ & 77.7 & 2.6 & $2.0-3.3$ & 33.5 & 1.4 & $0.9-2.2$ \\
\hline College graduate & 91.1 & 7.2 & $4.9-10.5$ & 50.0 & 3.0 & $1.7-5.3$ \\
\hline \multicolumn{7}{|l|}{ Geographic areał } \\
\hline Rurali & 69.1 & 1.0 & & 28.8 & 1.0 & \\
\hline Metropolitan & 82.9 & 2.2 & $1.7-2.9$ & 35.1 & 1.4 & $0.9-2.1$ \\
\hline Core cities & 80.9 & 1.9 & $1.5-2.4$ & 38.2 & 1.6 & $1.1-2.3$ \\
\hline \multicolumn{7}{|l|}{ Presence of local ordinance $\$$} \\
\hline No & 77.2 & 1.0 & & 33.6 & 1.0 & \\
\hline Yes & 79.5 & 1.2 & $0.9-1.6$ & 40.0 & 1.2 & $0.8-1.9$ \\
\hline \multicolumn{7}{|l|}{$\begin{array}{l}\text { ETS is harmful to } \\
\text { nonsmokers' health }\end{array}$} \\
\hline No & 41.2 & 1.0 & & 19.6 & 1.0 & \\
\hline Yes & 82.5 & 6.6 & $4.6-9.5$ & 41.3 & 2.8 & $1.8-4.4$ \\
\hline Don't know & 52.5 & 1.5 & $1.0-2.5$ & 24.4 & 1.3 & $0.7-2.3$ \\
\hline \multicolumn{7}{|l|}{ ETS is annoying } \\
\hline No & 51.4 & 1.0 & & 28.2 & 1.0 & \\
\hline Yes & 84.6 & 5.1 & $4.1-6.4$ & 47.7 & 2.3 & $1.6-3.2$ \\
\hline \multicolumn{7}{|l|}{ Smoking should be allowed } \\
\hline Anywhere & 46.0 & 1.0 & & 20.2 & 1.0 & \\
\hline Certain areas & 77.7 & 4.4 & $2.8-6.9$ & 35.1 & 2.2 & $1.2-3.9$ \\
\hline Not at all & 86.4 & 7.7 & $4.6-12.9$ & 50.0 & 3.9 & $1.6-10.1$ \\
\hline
\end{tabular}

For explanation of footnotes see table 3. 
Table 5 Likelihood of discussing the reduction of smoking in the workplace by sociodemographic grouping, geographic area, and beliefs about ETS, Missouri, 1991-92

\begin{tabular}{|c|c|c|c|c|c|c|}
\hline \multirow[b]{3}{*}{ Characteristic } & \multicolumn{6}{|c|}{ Discussed the reduction of workplace smoking } \\
\hline & \multicolumn{3}{|c|}{ Nonsmokers } & \multicolumn{3}{|c|}{ Smokers } \\
\hline & $\%$ * & OR† & $95 \% \mathrm{CI}$ & $\%$ * & ORt & $95 \% \mathrm{CI}$ \\
\hline \multicolumn{7}{|l|}{ Age (years) } \\
\hline & 22.0 & 1.0 & & 4.4 & 1.0 & \\
\hline $\begin{array}{l}35-54 \\
18-34\end{array}$ & 29.1 & 1.5 & $0.9-2.3$ & 9.8 & 2.3 & $0.5-21.2$ \\
\hline $\begin{array}{l}18-34 \\
\text { Gender }\end{array}$ & 25.9 & 1.2 & $0.8-1.9$ & 11.2 & & $0.7-27.5$ \\
\hline \multicolumn{7}{|l|}{ Gender } \\
\hline $\begin{array}{l}\text { Male } \\
\text { Female }\end{array}$ & 24.6 & 1.0 & & 9.6 & 1.0 & \\
\hline $\begin{array}{l}\text { Female } \\
\text { Race }\end{array}$ & 28.4 & 1.2 & $0.9-1.6$ & 10.2 & 1.0 & $0.5-1.8$ \\
\hline \multicolumn{7}{|l|}{ Race } \\
\hline $\begin{array}{l}\text { White } \\
\text { Black }\end{array}$ & 26.3 & 1.0 & & $\begin{array}{r}9.4 \\
16.7\end{array}$ & 1.0 & \\
\hline \multicolumn{7}{|l|}{$\begin{array}{l}\text { Black } \\
\text { Educational level }\end{array}$} \\
\hline $\begin{array}{l}\text { Less than high } \\
\text { school graduate }\end{array}$ & 19.6 & 1.0 & & 4.0 & 1.0 & \\
\hline $\begin{array}{l}\text { High school or technical } \\
\text { school graduate }\end{array}$ & 27.1 & 1.6 & $0.9-2.7$ & 10.7 & 2.2 & $0.7-8.7$ \\
\hline College graduate & 27.8 & 1.6 & $0.9-3.0$ & 13.5 & 3.7 & $0.9-17.0$ \\
\hline \multicolumn{7}{|l|}{ Geographic area } \\
\hline Rural & 23.5 & 1.0 & & 7.3 & 1.0 & \\
\hline Metropolitan & 29.2 & 1.3 & $0.9-1.9$ & 12.2 & 1.9 & $0.8-4.4$ \\
\hline Core cities & 27.2 & 1.3 & $0.9-1.8$ & 11.1 & 1.8 & $0.8-3.9$ \\
\hline \multicolumn{7}{|l|}{ Presence of local ordinance $\$$} \\
\hline No & 26.4 & 1.0 & & 9.8 & 1.0 & \\
\hline Yes & 28.6 & 0.8 & $0.5-1.2$ & 13.0 & 0.9 & $0.4-2.1$ \\
\hline \multicolumn{7}{|l|}{ ETS is harmful to } \\
\hline $\begin{array}{l}\text { nonsmokers' health } \\
\text { No }\end{array}$ & 3.3 & 1.0 & & 3.3 & 1.0 & \\
\hline Yes & 29.1 & 12.1 & $3.1-102.5$ & 13.6 & 3.6 & $1.2-14.0$ \\
\hline Don't know & 10.9 & 3.4 & $0.6-35.0$ & 4.0 & 0.9 & $0.1-5.5$ \\
\hline \multicolumn{7}{|l|}{ ETS is annoying } \\
\hline No & 10.5 & 1.0 & & 8.2 & 1.0 & \\
\hline Yesפ & 30.3 & 3.6 & $2.2-6.1$ & 14.1 & 1.9 & $1.0-3.7$ \\
\hline \multicolumn{7}{|l|}{ Smoking should be allowed } \\
\hline Anywhere & 2.0 & 1.0 & & 6.6 & 1.0 & \\
\hline Certain areas & 25.9 & 17.3 & $17.3-701$ & 9.7 & 1.7 & $0.6-6.6$ \\
\hline Not at all & 36.1 & 28.1 & $4.6-1146$ & 19.1 & 3.4 & $0.6-19.7$ \\
\hline
\end{tabular}

For explanation of footnotes see table 3.

aware of the harmful effects of ETS exposure, persons who were annoyed by ETS, and respondents who favoured restrictions on smoking in public places (table 5).

\section{Discussion}

In our population-based survey data, we identified several predictors of higher individual action to reduce ETS exposure. The strongest sociodemographic predictors of low actions to reduce ETS exposure included younger age, city residence, and higher education level. Additionally, actions to reduce ETS exposure were lower among respondents unaware of the health consequences of ETS, among persons who were not annoyed by ETS exposure, and among respondents who did not favour restrictions on smoking in public places. Actions that may be perceived as less confrontational (eg, asking for a nonsmoking section in a restaurant) were generally more common.

Although few previous studies have reported similar data, a recent California study ${ }^{24}$ used telephone survey methods to assess responses to the question: "In the past 12 months, have you ever asked someone not to smoke in a certain situation?" In the California study, a majority of nonsmokers $(59.1 \%)$ and almost half of smokers $(44.4 \%)$ reported having asked in certain situations. These percentages are considerably higher than those we observed. A higher level of individual action in California compared with other areas of the US would not be unexpected considering the 1988 en- actment of California Proposition 99, with its aggressive media campaign ${ }^{25,26}$ and more common local smoking control restrictions in California. ${ }^{27}$ The wording of questions also varied between Missouri and California. Consistent with our results, Elder $e t a l^{24}$ observed more activism among younger respondents and among persons more aware of the health effects of ETS exposure.

Conversely, the level of individual action in our study was considerably higher than findings reported by Davis et al. ${ }^{28}$ Based on analysis of the 1987 National Health Interview Survey (NHIS), only $4 \%$ of nonsmokers asked a smoker not to smoke in their presence. ${ }^{28}$ However, an important distinction between this study and ours may be that nonsmokers in the NHIS were asked if they take action after the smoker lights up.

Canadian data on compliance with smoking restrictions in public places have shown higher compliance for females and younger respondents. ${ }^{29}$ In addition, knowledge of the health effects of ETS exposure was higher among city and more educated populations. ${ }^{29}$.

Numerous perspectives in behavioural science (eg, the health belief model ${ }^{30,31}$ ) assert that an individual needs to feel susceptible to a health risk prior to taking action to change behaviour. This model appears to be supported by our data showing the low level of individual action among persons unaware of the health effects of ETS exposure.

The current CDC national public information campaign on ETS risks (ie, "Secondhand Smoke: We're All At Risk") includes 
television advertisements, print and radio advertisements, and an action guide for the public $^{11}$ (see Tobacco Control 1993; 2: 326). Supporting this and similar public education activities, a substantial percentage of respondents either believed that ETS exposure was not harmful to nonsmokers $(10.0 \%)$ or did not know if ETS were harmful $(9.6 \%)$. Among these subgroups, the level of actions to reduce ETS exposure was substantially lower than among persons who knew that ETS is harmful to nonsmokers. BRFSS data such as ours will aid in evaluating the effects of educational campaigns, policy changes, and release of risk assessments such as the recent report from the US EPA. ${ }^{4}$

It is well documented that smoking is much more common among groups with lower education levels. ${ }^{32-35}$ Similarly, in our data, non-high school graduates were less likely to take action to reduce ETS exposure than were those with a high school or college education.

The limitations of our study should be noted. We relied on self-reported telephone survey data and had no comprehensive information on the accuracy of the BRFSS data during the study period. However, previous studies ${ }^{36,37}$ have shown relatively high accuracy of BRFSS-collected data on reported cardiovascular risk factors and demographics. For variables that have been measured previously, our data compared closely to other studies. For example, we found that $80.2 \%$ of respondents knew ETS was harmful to nonsmokers, which compares with $78 \%$ in an earlier Missouri study ${ }^{19}$ and $81 \%$ in national studies. ${ }^{18,28,38}$ In addition, a 1993 test-retest study of the Missouri BRFSS found relatively high reliability for questions involving individual actions to reduce exposure to ETS (kappa values 0.62 to 0.82$){ }^{39}$ Since BRFSS relies on telephone interviews, the potential exists for response bias due to lack of phone coverage among certain sociodemographic groups. ${ }^{40}$

Because of the limited number of questions available for analysis, we were unable to differentiate some important measurement issues. For example, our question on whether respondents had asked someone not to smoke in their presence cannot discriminate between friends, family members, co-workers, or strangers. Similarly, discussion of workplace smoking reduction cannot differentiate whether discussion was among co-workers, management, or trades unions. Finally, our survey asked whether action regarding ETS had been taken during the past year, and affirmative responses may have included cases in which the respondent had taken such action only once. Questions that inquired about the frequency of actions taken to avoid ETS - eg, whether the respondent usually requests to be seated in the nonsmoking area of a restaurant - might yield different results.

In summary, our study identified certain population subgroups that were more likely to advocate for protection from the harmful effects of ETS. With the advent of policyoriented projects such as the American Stop Smoking Intervention Study, ${ }^{41}$ data such as ours may be useful in targeting efforts to population segments. Despite the large body of literature on the health effects of ETS exposure, few studies are available on policy and advocacy issues. ${ }^{42}$ Additional research in this area will be helpful in targeting and refining public health messages to reduce exposure to ETS.

The authors are grateful to supervisors and surveyors from Manpower, Inc, who conducted data collection; to Larry Manpower, Inc, who conducted data collection; to Larry Fowler and Florence Mueller for assistance in identifying local
smoking control ordinances; and to Drs Dileep Bal, Gary smoking control ordinances; and to Drs Dileep Bal, Gary Giovino, Thomas Novotny, and
suggestions on the manuscript

This study was supported in part by Centers for Disease
Thestions on the manuscript. Control and Prevention contract U58/CCU700950.

1 US Department of Health and Human Services. The health consequences of involuntary smoking. A report of the
Surgeon General, 1986. Washington, DC: US Department of Health and Human Services, Public Health ment of Health and Human Services, Public Health Service, Centers for Disease Cont
Publication No (CDC) 87-8398.)

2 National Research Council. Board on Environmental Studies and Toxicology. Committee on Passive Smoking: Environmental tobacco smoke. Measuring exposures and assessing health effects. Washington, DC: National Academy Press; 1986.

3 National Institute for Occupational Safety and Health. Current Intelligence Bulletin 54. Environmental tobacco smoke in the workplace. Lung cancer and other health
effects. Cincinnati, Ohio: National Institute for Occupational Safety and Health, 1991. (DHSS Publication No 91-108.)

4 US Environmental Protection Agency. Respiratory health effects of passive smoking : lung cancer and other disorders. Wects of passive smoking: lung cancer and other disorders. Washington, DC: US Environm

5 Glantz SA, Parmley WW. Passive smoking and heart disease: epidemiology, physiology, and biochemistry. Circulation 1991; 83: 1-12.

6 Schoendorf KC, Kiely JL. Relationship of sudden infant death syndrome to maternal smoking during and after pregnancy. Pediatrics 1992; 90: 905-8.

7 Pertschuk M, Shopland DR, eds. Major local smoking ordinances in the United States: a detailed matrix of the provisions of workplace, restaurant, and public places smoking ordinances. Rockville, Maryland: National Institutes of Health, Public Health Service, 1989. (NIH Publication No 90-479.)

8 Rigotti NA, Pashos CL. No-smoking laws in the United States. An analysis of state and city actions to limit States. An analysis of state and city actions to limit
smoking in public places and workplaces. $\mathscr{F} A M A$ 1991;

9 Borland R, Pierce JP, Burns DM, Gilpin E, Johnson M, Bal D. Protection from environmental tobacco smoke in California. The case for a smoke-free workplace. $\mathcal{f} A M A$ 1992; 268 : 749-52.

10 US Centers for Disease Control and Prevention. Preliminary data: exposure of persons aged $\geqslant 4$ years to tobacco smoke. MMWR 1993; 42: 37-9.

11 US Department of Health and Human Services. HHS news. [Press release]. Washington, DC: US DHHS, 7 January 1993.

12 Gentry EM, Kalsbeek WD, Hogelin GC, et al. The Behavioral Risk Factor Surveys: design, methods, and estimates from combined state data. Am $\mathcal{F}$ Prev Med $1985 ; 1: 9-14$

13 Remington PL, Smith MY, Williamson DF, Anda RF, Gentry EM, Hogelin GC. Design, characteristics, and usefulness of state-based behavioral risk factor surveillance: 1981-1987. Public Health Rep 1988; 103: 366-75.

14 Siegel PZ, Brackbill RM, Frazier EL, et al. Behavioral risk factor surveillance, 1986-1990. MMWR 1991; 40(SS-4): $1-23$.

15 Waksberg J. Sampling methods for random digit dialing. $\mathcal{J}$ Am Stat Assoc 1978; 73 : 40-6.

16 US Department of Commerce. 1990 census of population and housing short form. Washington, DC: US Department of Commerce, Bureau of the Census, 1992.

17 US Centers for Dise of Che attitudes, and exposures - United States, 1986. MMWR 1988; 37: 239-41.

18 Pierce JP, Hatziandreu E, Flyer $\mathrm{P}$, et al. Tobacco use in 1986: methods and basic tabulations from adult use of 1986: methods and basic tabulations from adult use of tobacco survey. Rockville, Maryland: US Department of Health and Human
No OM 90-2004.)

19 Brownson RC, Jackson-Thompson J, Wilkerson JC, Davis JR, Owens NW, Fisher EB Jr. Demographic and socioeconomic differences in beliefs about the health effects of smoking. Am $\mathcal{Y}$ Public Health 1992; 82: 99-103.

20 Statistical Analysis System Institute Incorporated. $S A S$ User's Guide: Basics, Version 5 Edition. Cary, North Carolina: SAS Institute Inc, 1985.

21 SUDAAN User's Manual. Professional software for survey 
data analysis. Research Triangle Park, North Carolina: Research Triangle Institute, 1991.

22 Fleiss JL. Statistical methods for rates and proportions. New York: John Wiley, 1981

23 Mehta CR, Patel NR, Gray R. Computing an exact confidence interval for the common odds ratio in several $2 \times 2$ contingency tables. $\mathcal{F}$ Am Stat Assoc 1985; 78: $969-73$.

24 Elder J, Rosbrook B, Choi W, Johnson M, Bal D, Pierce JP. Public objections to environmental tobacco smoke. Prev Public objections to en

25 Bal DG, Kizer KW, Felten PG, Mozar HN, Niemeyer D. Reducing tobacco consumption in California: development of a statewide anti-tobacco use campaign. $\mathcal{F} A M A$ $1990 ; 264: 1570-4$.

26 Breslow L, Johnson M. California's Proposition 99 on tobacco, and its impact. Annu Rev Public Health 1993; 14: 585-604.

27 National Cancer Institute. Major local smoking ordinances in the United States. Smoking and Tobacco Control Monograph No 3. Bethesda, Maryland: National Institutes of Health, Public Health Service, 1993. (NIH Publication No 93-3532.

28 Davis RM, Boyd GM, Schoenborn CA. "Common courtesy" and the elimination of passive smoking: results of the 1987 National Health Interview Survey, $f A M A$ $1990 ; 263: 2208-10$ (and erratum in $¥ A M A 1990 ; \mathbf{2 6 3}$ : 3025)

29 Pederson LL, Bull SB, Ashley MJ, Lefcoe NM. A population survey of legislative measures to restrict smoking in Ontario: 4. Variables related to knowledge of active and passive smoking health effects and to predicted behavior of smokers and nonsmokers. Am $₹$ Prev Med 1989; 5: 323-9

30 Rosenstock IM: The health belief model and preventive health behavior. Health Educ Monogr 1974; 2: 354-86.

31 Maiman LA, Becker MH. The health belief model: origins and correlates in psychological theory. Health Educ Monogr $1974 ; 2: 336-53$.
32 Novotny TE, Warner KE, Kendrick JS, Remington PL. Smoking by blacks and whites: socioeconomic and demographic differences. Am F Public Health 1988; 78 : 1187-9.

33 Pierce JP, Fiore MC, Novotny TE, et al. Trends in cigarette smoking in the United States. Educational differences are increasing. $7 A M A 1989 ; 261$ : 56-60.

34 US Department of Health and Human Services. Reducing the health consequences of smoking: 25 years of progress: a the health consequences of smoking: 25 years of progress: a report of the Surgeon General, 1989. Atlanta, Georgia: US Centers for Disease Control, Office on Smokin

35 US Centers for Disease Control. Cigarette smoking among adults - United States, 1991. MMWR 1993; 42: 230-3. 36 Shea S, Stein AD, Lantigua R, Basch CE. Reliability of the Behavioral Risk Factor Survey in a triethnic population. Am $\mathcal{F}$ Epidemiol 1991; 133: 489-500.

37 Jackson C, Jatulis DE, Fortmann SP. The Behavioral Risk Factor Survey and the Stanford Five-City Project Survey: a comparison of cardiovascular risk behavior estimates. Am F Public Health 1992; 82: 412-6.

38 American Cancer Society. 1987 survey of public awareness and use of cancer tests. New York: American Cancer Society, 1988.

39 Brownson RC, Jackson-Thompson J, Wilkerson JC, Kiani F. Reliability of information on chronic disease risk factors collected in the Missouri Behavioral Risk Factor Surveillance System. Epidemiology, in press.

$40 \mathrm{US}$ Centers for Disease Control and Prevention. Using chronic disease data: a handbook for public health practitioners. Atlanta, Georgia: Centers for Disease Control and Prevention, 1992.

41 Siegfried J. Largest tobacco-control program begins. 7 Natl Cancer Inst $1991 ; 83: 1446-7$.

42 Chapman S. Upgrading the academic respectability of advocacy studies. Tobacco Control 1992; 1: 81-3.
$=-$

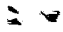

Early European observers appreciated that the peoples of the Western Hemisphere used tobacco to achieve pharmacologic effects. The following is the first English description of tobacco use. It is a translation from the French, published in 1568 (MacInnes CM. The early English tobacco trade. London: Kegan Paul, Trench, Trubner \& Co, Ltd, 1926, pp 19-20). In describing customs of the people native to Brazil, André Thevet noted,

There is another secrete herbe which they name in their language 'Petun,' the which most commonly they beare about them, for that they esteem it marvellous proffitable for many things, this herbe is like to our Buglos. They gather this herbe very charely (cf. chary - careful) and dry it within their little cabanes or houses. Their manner to use it is this, they wrappe a quantitie of this herbe being dry in a leafe of a Palme tree, which is very great, and so they make rolles of the length of a candle, and then they fire the one end and receive the smoke thereof by their nose and by their mouthe. They say it is very holesome to clense and consume the superfluous humours of the brain. Moreover, being taken after this sort, it kepeth the parties from hunger and thirst for a time, therefore they use it ordinarily. Also, when they have any secret talke or counsel among themselves, they draw this smoke and then they speake. The which they do customably the one after the other in the warre, whereas it is very needful. The women use it by no means. If they take too much of this parfume, it will make them light in the head as the smell or taste of strong wine[.] The Christians that do now inhabite there, are become very desirous of this parfume, although that the first use thereof is not without danger, before that one is accustomed thereto, for this smoke causeth sweates and weaknesse even to fall into 'syncope' which I have tried in my selfe.

André Thevet

The New Founde Worlde or Antarctike, 1568

Contributed by John Slade

Robert Wood Johnson Medical School St Peter's Medical Center, New Brunswick, New Jersey, USA 